\title{
Sistem Informasi Buku Tamu Menggunakan Qr code Berbasis Web Pada PT Petrokimia Gresik
}

\author{
Aldhiqo Yusron Mubarok ${ }^{1}$, Umi Chotijah ${ }^{2}$ \\ Fakultas Teknik, Program Studi Teknik informatika \\ Universitas Muhammaddiyah Gresik \\ aldiqoym@gmail.com
}

\begin{abstract}
Abstrak
Corona merupakan wabah yang sedang menyerang seluruh dunia pada tahun 2020 . Banyaknya korban jiwa baik dalam ruanglingkup pekerjaan maupun masyarakat umum membuat virus ini sangat berbahaya. Petrokimia Merupakan salah satu industri pupuk terbesar di dunia, dengan jumlah karyawan yang mencapai 3000 karyawan. Dalam hal penanganan dari penyebaran virus tersebut peneliti membuat sebuah Sistem Informasi Buku Tamu Petrokimia Gresik Menggunakan Qr Code Berbasis Web yang dapat digunakan untuk menerima tamu yang akan berkunjung pada Petrokimia, agar karyawan Petrokimia lebih aman dalam menerima tamu tanpa melakukan kontak fisik dengan Tamu yang berkunjung. Sistem ini dibuat dengan menggunakan metode waterfall dan dibuat dengan bahasa pemerograman PHP dengan MySQL sebagai sistem basis data. Hasil user acceptance test menunjukkan bahwa semua fitur sistem bekerja dengan baik dan diterima oleh pengguna.
\end{abstract}

Kata kunci: corona, buku tamu, Qr code, website

\begin{abstract}
Corona is an epidemic that is currently attacking the entire world in 2020. A large number of casualties both in the scope of business and the general public makes this virus very dangerous. Petrokimia is one of the largest fertilizer industry in the world, with a total of 3000 employees. In terms of handling the spread of the virus, the authors created a system of web-based application guestbook using Qr code that can be used to record guests visiting Petrokimia, so that Petrokimia employees are safer in receiving guests without making physical contact with the guests. This system was built using the waterfall method made with PHP language with MYSQL as the system of the database. User acceptance test show that all the features on system works really well and it has been accepted by users.
\end{abstract}

Keywords: corona, guest book, Qr code, website

\section{PENDAHULUAN}

Virus corona adalah virus yang menyerang seluruh dunia dan diakui sebagai wabah pada 2020. Virus Corona yang menyebabkan COVID-19 bisa menyerang siapa saja. Menurut data yang dirilis Gugus Tugas Percepatan Penanganan COVID-19 Republik Indonesia, jumlah kasus terkonfirmasi positif hingga 11 Januari 2021 adalah
828.026 orang dengan jumlah kematian 24.129 orang. Kematian yang disebabkan oleh COVID-19 adalah sekitar 2,9\%. Dari tingkat persentase angka kematian hingga saat ini, maka usia 46-59 tahun memiliki angka yang tertinggi dibandingkan dengan golongan usia lainnya. Sedangkan, apabila dilihat dari jenis kelamin, 56,5\% penderita yang meninggal akibat COVID-19 adalah 
laki-laki dan 43,5\% lainnya adalah perempuan.

Dalam mengatasi masalah ini, banyak perusahaan Indonesia pada bidang industri maupun non industri, melakukan upaya pencegahan virus corona dengan membatasi jumlah karyawan hingga melakukan pengurangan pegawai.

Petrokimia adalah salah satu perusahaan industri terbesar di dunia, yang memiliki banyak pengunjung atau tamu, mulai dari mahasiswa hingga rekan bisnis. Dalam penerimaan tamu hingga sekarang Petrokimia melakukannya dengan menggunakan buku tamu manual yakni dengan tulisan tangan. Dengan proses penerimaan tamu seperti ini dikawatirkan para karyawan Petrokimia akan melakukan kontak fisik dengan tamu baik secara langsung maupun dengan perantara seperti pulpen, kertas, dll.

Maka dengan uraian diatas diusulkan pembuatan "sistem informasi buku tamu menggunakan qr code pada Petrokimia berbasis web" untuk membantu mengatasi masalah tersebut.

\section{Rumusan Masalah}

Rumusan masalah dari penelitian ini adalah :

1. Bagaimana cara untuk mengurangi potensi karyawan agar tidak melakukan kontak fisik secara langsung dengan tamu?

2. Bagaimana cara membangun sistem informasi buku tamu berbasis web?

3. Bagaimana hasil uji penerimaan pengguna (user acceptance test) sistem informasi buku tamu berbasis web?

\section{Tujuan Penelitian}

Tujuan dari penelitian ini adalah sebagi berikut :
1. Merancang dan mengimplementasikan sistem aplikasi buku tamu berbasis web pada Petrokimia Gresik

2. Untuk memudahkan para tamu dan karyawan yang akan berkunjung maupun menerima tamu pada Petrokimia Gresik

\section{Manfaat Penelitian}

Manfaat dari penilitian ini adalah sebagai berikut:

1. Sebagai salah satu alternatif untuk mengurangi resiko penyebaran virus corona dengan membatasi kontak fisik dengan tamu yang akan berkunjung.

2. Sebagai sarana untuk mencatat data tamu yang berkunjung ke Petrokimia Gresik

\section{Tinjauan Pustaka}

Penelitian yang dilakukan oleh (Muliyadi,2019) dengan judul Aplikasi Buku Tamu Elektronik Pada Perpustakaan STIKOM Dinamika Bangsa. Aplikasi yang dikembangkan digunakan untuk mempermudah tamu perpustakaan untuk mengisi data kunjungan pada buku tamu, dikarenakan antrian yang panjang sehingga tamu cenderung malas mengisi buku tamu. Penelitian ini menghasilkan sebuah aplikasi buku tamu elektronik yang menggunakan teknologi barcode untuk perpustakaan STIKOM DB Jambi yang mempermudah dan mempercepat proses perekaman kehadiran pengunjung di perpustakaan serta dilengkapi dengan informasi statistik kehadiran pengunjung, usulan pengadaan bahan bacaan serta kualitas layanan dan prasarana melalui kritik dan saran yang disampaikan pengunjung.

Penelitian yang dilakukan oleh (Rut Chrystin Saragi Napitu dkk, 2020) dengan judul Perancangan Sistem Absensi 
Berbasis Web pada Program Studi PTI UNIMUDA Sorong. Sistem yang dikembangkan peneliti ini, digunakan untuk mempermudah serta memperkuat keamanan arsip data absensi mahasiwa di UNIMUDA yang masih menggunakan kertas atau manual. Beberapa tahapan yang dilakukan oleh peneliti untuk membuat sebuah sistem absensi berbasis web antara lain, pengumpulan data, perencanaan, pengembangan bentuk awal produk, uji lapangan dan revisi produk, dan yang terakhir adalah implementasi. Hasil penilaian yang dihasilkan dari pengujian produk mendapatkan nilai yang baik, yakni dengan rata - rata sebesar 87,31. Sehingga dapat disimpulkan bahwa sistem absensi berbasis web ini layak digunakan.

\section{LANDASAN TEORI}

\section{Sistem}

Sistem merupakan suatu kumpulan atau rangkaian komponen-komponen yang saling berhubungan dan bekerja sama serta saling berinteraksi untuk mencapai suatu tujuan dengan melalui tiga tahapan input (masuk), proses dan output (keluar) (Fery Wongso, 2016 : 163).

\section{Sistem Informasi}

Sistem Informasi adalah suatu kombinasi dari orang-orang, perangkat keras, perangkat lunak, jaringan komunikasi, sumber daya data, kebijakan dan prosedur dalam mengubah, mendapatkan kembali, menyimpan, serta menyebarkan informasi dalam suatu organisasi (Marakas \& O'Brien, 2017).

\section{Web Server}

Web Server adalah perangkat lunak server yang memiliki fungsi untuk menerima permintaan dalam bentuk situs web melalui HTTP atau HTTPS dari klien, yang dikenal sebagai web browser dan mengirimkan kembali (reaksi) hasil dalam bentuk situs yang biasanya merupakan dokumen HTML.

(Supono dan Putratama,2016:6).

\section{Website}

Website adalah sekumpulan halaman yang terdiri dari beberapa laman yang berisi informasi dalam bentuk data digital baik berupa text, gambar, video, audio, dan animasi lainnya yang disediakan menggunakan jalur internet. Webiste juga dapat diartikan sebagai halaman-halaman yang ditampilkan oleh browser seperti Mozila Firefox, Google Chrome atau lainnya yang berisi informasi. ( Rohi Adulloh,2016)

\section{PHP}

PHP (PHP:Hypertext Preprocessor) adalah suatu bahasa pemrograman yang berfungsi untuk menerjemahkan baris kode program menjadi kode mesin yang dapat dimengerti oleh komputer, berbasis server-side yang dapat ditambahkan ke dalam HTML. (Supono dan Putratama,2016:3)

\section{CSS}

CSS atau cascading style sheet bahasa pemrograman yang diusulkan oleh Hakon Wilum Lie pada tahun 1994 dan distandarisasi oleh $W 3 C$ yang berfungsi untuk mempercantik tampilan web (Solichin, 2016:10).

\section{$M y S Q L$}

MySQL adalah suatu sistem manajemen Database SQL yang bersifat Open Source. Sistem Database MySQL memiliki beberapa fitur yakni multithreaded, multiuser dan SQL 
Database managemen system (DBMS) ( Madcoms, 2016).

\section{XАMPP}

Xampp adalah sebuah kumpulan paket software yang terdiri dari Apache, Filezilla, MySQL, PhpMyAdmin, PHP, Perl, dan lain-lain (Madcoms, 2016).

\section{QR Code}

$Q R$ Code adalah teknik yang mengubah data tertulis menjadi kode-kode 2- dimensi yang tercetak ke dalam suatu media yang lebih ringkas. $Q R$ Code merupakan 2- dimensi yang diperkenalkan pertama kali oleh perusahaan Jepang Denso-Wave pada tahun 1994. Barcode pertama kali digunakan untuk pendataan invertaris produksi suku cadang kendaraan dan sekarang sudah digunakan dalam berbagai bidang. QR merupakan singkatan dari Quick Response, berfungsi untuk menerjemahkan isi dengan cepat. Rahaman (2016) menerangkan bahwa melalui QR Code apapun bisa dirubah menjadi sebuah informasi yang dapat diakses dengan cepat. QR Code juga memiliki kemampuan untuk menyimpan data dan informasi didalamnya (Wijaya \& Gunawan, 2016).

\section{METODE PENELITIAN}

Metode yang peneliti gunakan pada penelitian ini adalah metode waterfall. Metode waterfall atau metode air terjun merupakan salah satu siklus hidup klasic (Classic life cycle) dalam pengembangan perangkat lunak. Metode Waterfall menggambarkan pendekatan yang sistematis juga berurutan terhadap pengembangan software, mulai dari :

- Spesifikasi kebutuhan pengguna
- Perencanaan

- Permodelan

- Konstruksi

- Penyerahan sistem ke pengguna

- Serta perawatan sistem

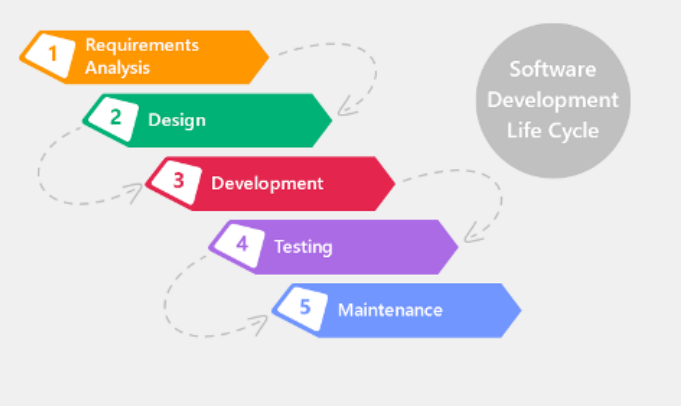

Gambar 1 model waterfall

1. Requirement (kebutuhan)

Dengan informasi yang telah didapat peneliti, yakni dengan cara wawancara, survey, dan diskusi, peneliti memutuskan untuk membuat sebuah sistem baru dengan menggunakan web sebagai solusi untuk memecahkan salah satu masalah yang dihadapi Petrokimia Gresik. Data yang telah diperoleh sangat penting untuk membuat fitur - fitur sistem yang nantinya akan dibuat oleh peneliti.

2. Design (desain / model)

Sistem Informasi Buku Tamu Menggunakan $Q R$ code Berbasis Web dimulai dengan membuat flowchart yang diusulkan dan membuat diagram konteks, serta perancangan basis data dan perancangan tampilan untuk input dan output.

3. Implementation (implementasi)

Tahapan ini adalah tahapan dimana pengkodingan dimulai. Bahasa pemerograman yang digunakan penulis untuk membuat sistem informasi ini adalah bahasa PHP dan MySQL sebagai sistem basis datanya. 
4. Integration \& Testing (integrasi \& proses test)

Pada tahap keempat ini akan dilakukan penggabungan modul-modul yang sudah dibuat sebelumnya. Setelah itu akan dilakukan pengujian yang bertujuan untuk mengetahui sistem yang telah dibuat peneliti sudah sesuai desain yang diinginkan dan apakah masih ada kesalahan atau tidak.

5. Operation \& Maintenance

Operation \& Maintenance adalah tahapan terakhir dari metode pengembangan waterfall. Sistem informasi buku tamu menggunakan $Q R$ code akan dioperasikan oleh peneliti atau pihak karyawan Petrokimia yang nantinya akan menjadi penggunanya. Disamping itu dilakukan pula pemeliharaan yang termasuk:

- perbaikan kesalahan

- perbaikan implementasi unit sistem

- peningkatan jasa sistem sesuai kebutuhan baru

\section{Kerangka Berpikir}

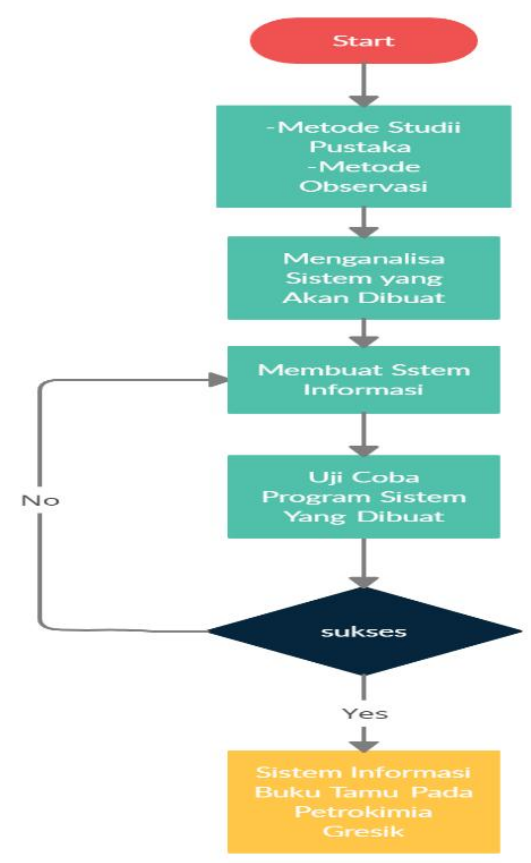

Gambar 2 . kerangka berfikir

\section{ANALISIS DAN PERANCANGAN}

Proses penerimaan tamu di Petrokimia Gresik dilakukan dengan cara manual yakni dengan bertatap muka dengan tamu. Proses yang terjadi jika bertamu adalah tamu akan datang kepada resepsionis perusahaan, kemudian mencatat keperluan yang hendak dilakukan pada perusahaan pada sebuah buku tamu. Proses ini mempunyai resiko kontak fisik dengan tamu yang akan datang dengan karyawan Petrokimia, baik secara langsung maupun dengan perantara bulpoin atau kertas. Dari permasalahan yang sudah teridentifikasi pada sistem yang sedang berjalan maka peneliti mengusulkan sebuah sistem yang diharapkan dapat merubah proses penerimaan tamu yang awalnya manual menjadi digital. Proses penerimaan secara daring melalui situs web dapat memudahkan pihak Petrokimia mencatat tamu yang telah datang, serta mengamankan pihak tamu dan karyawan di masa pandemi. Berikut merupakan alur sistem yang diusulkan:

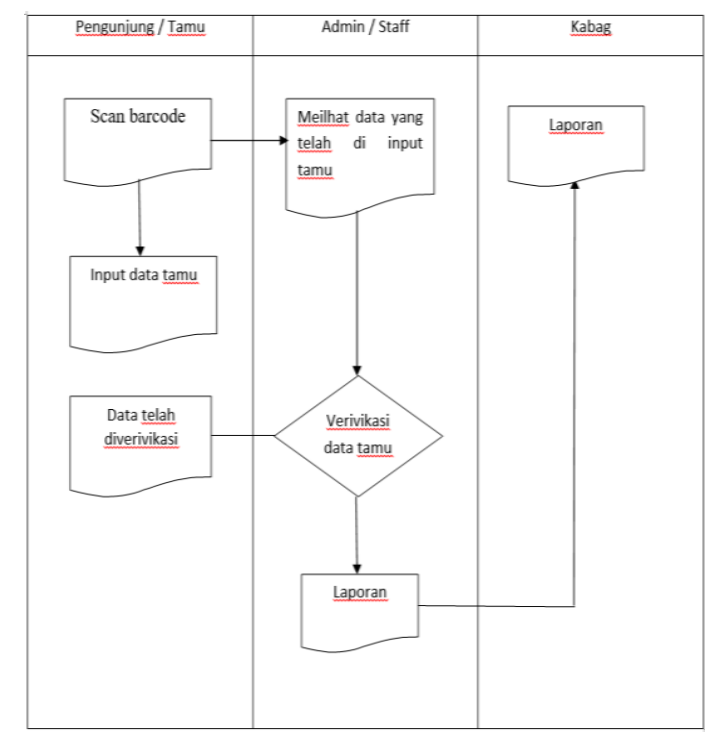

Gambar 3 sistem yang diusulkan 
Flowchart sistem penerimaan tamu

Flowcart adalah suatu bagan dengan simbol-simbol tertentu yang menggambarkan urutan proses secara mendetail dan hubungan antara suatu proses (instruksi) dengan proses lainnya dalam suatu program. Proses penerimaan tamu yang diusulkan adalah sebagai berikut :

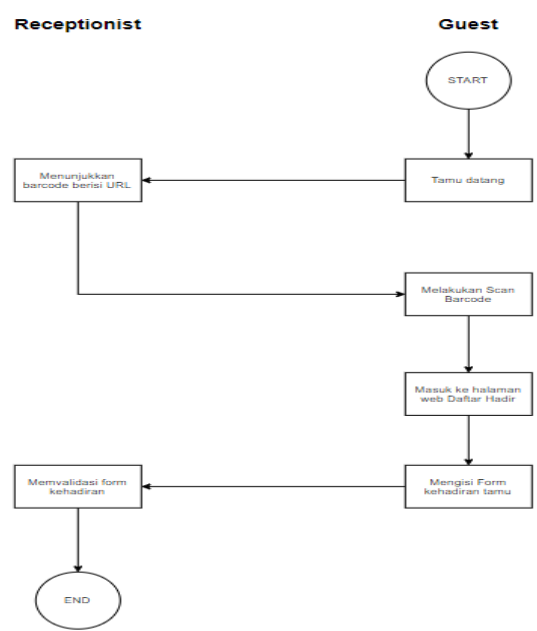

Gambar 4 flowchart sistem yang dibuat

\section{Kebutuhan Perangkat}

Perangkat keras yang dibutuhkan :

1. Laptop acer

2. Processor Intel $\AA$ Celeron $\AA$ Processor N3050 (1.6 GHz, 2M Cache)up to $2.16 \mathrm{GHz}$

3. Printer

4. Hardisk $500 \mathrm{gb}$

Sedangkan untuk perangkat lunak adalah sebagai berikut :

1. Sistem Operasi Windows 10

2. HTML, CSS, JS dan PHP sebagai scriptProgramming

3. MySQL untuk database

4. Browser seperti Crome

5. Xampp 3.2.4 sebagai server

6. Visual code sebagai code editor

7. CSS untuk mendesain tampilan web

\section{Use Case Diagram}

Use case diagram merupakan bagian tertinggi dari fungsionalitas yang dimiliki sistem yang akan menggambarkan bagaimana seseorang atau aktor akan menggunakan atau memanfaatkan sistem. Berikut merupakan use case diagram sistem inforasi buku tamu:

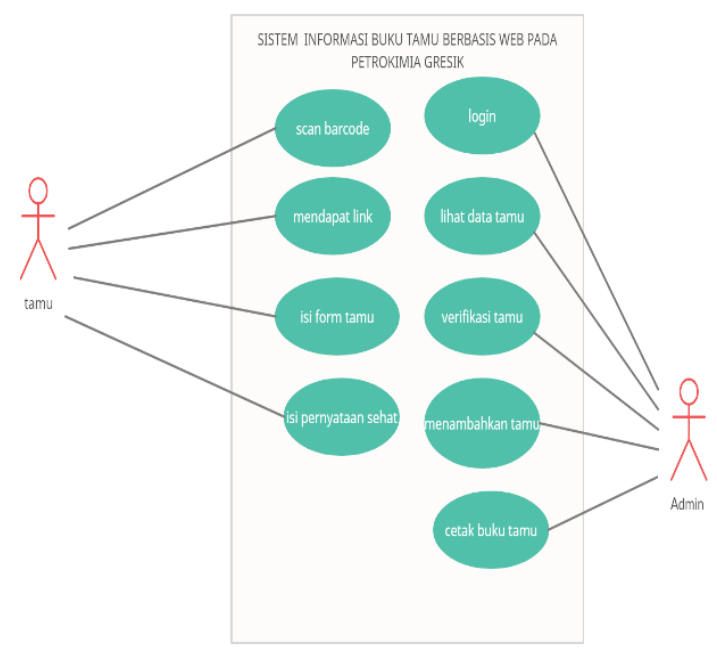

Gambar 5 use case diagram

\section{Diagram Konteks}

Diagram konteks adalah diagram yang tidak detail dari sebuah sistem informasi yang menggambarkan aliran data masuk dan keluar dari sistem.

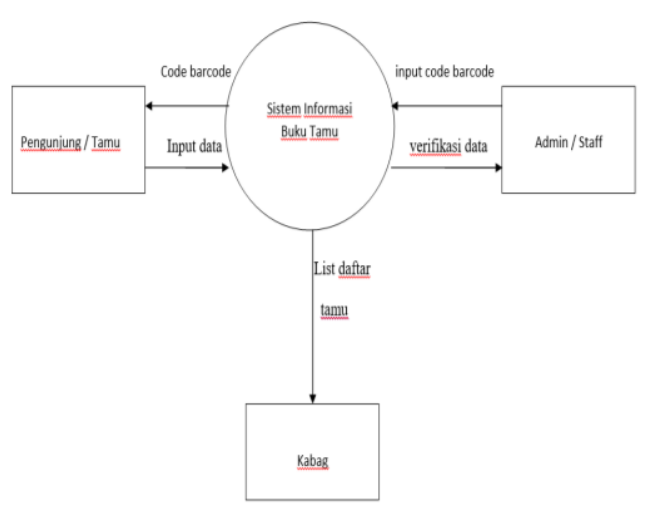

Gambar 6 Diagram konteks

\section{ERD (Entity Relationship Diagram)}

$E R D$ adalah suatu suatu model yang berfungsi untuk menyusun database dengan tujuan untuk menggambarkan data 
yang memiliki relasi dengan database sesuai dengan desain yang dibuat.

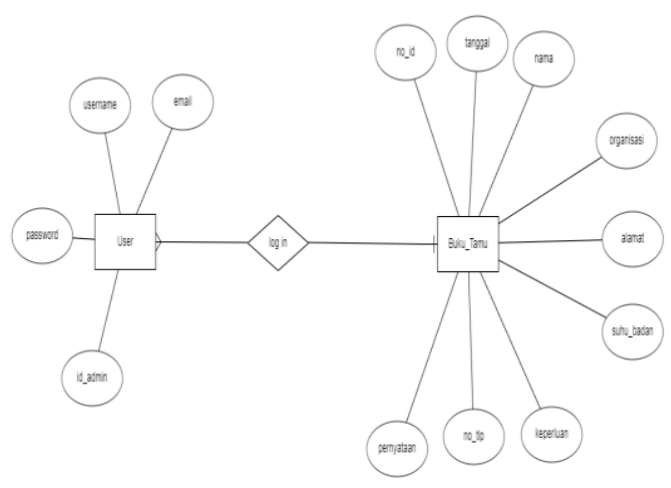

Gambar 7 ERD buku tamu

\section{IMPLEMENTASI DAN PEMBAHASAN}

\section{Menu Home}

Menu home adalah sebuah halaman awal pada sistem informasi buku tamu, Dimana home hanya bisa diakses oleh admin atau pegawai Petrokimia yang diberikan akses oleh pihak admin.

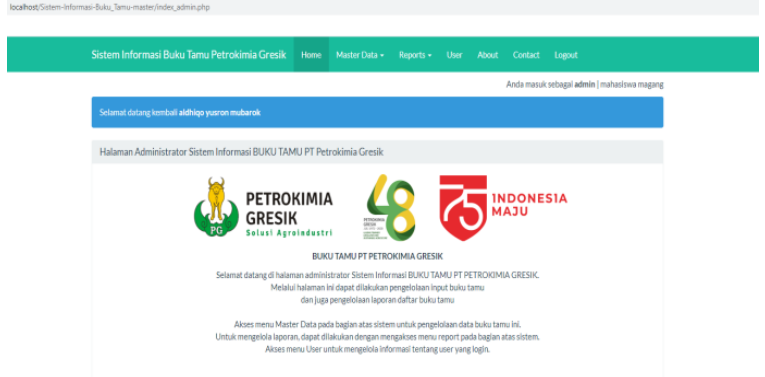

Gambar 8 homepage

\section{QR Code}

$Q R$ Code berfungsi untuk memberikan link bagi para tamu, untuk mengakses halaman input data tamu pada sistem informasi buku tamu. Setelah $Q R$ code di scan oleh tamu akan muncul sebuah link yang akan memberikan akses tamu untuk mengisi data dan pernyataan sesuai dengan yang tertera pada gambar : https://localhost/Sistem-InformasiBuku_Tamumaster/index.php?page $=$ data $\&$ actions $=$ tam $\mathrm{u}$

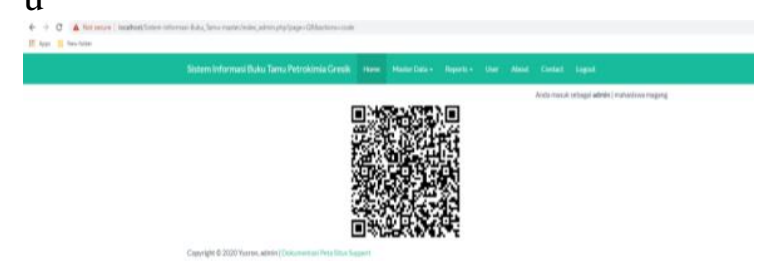

Gambar 9 halaman $Q R$ code

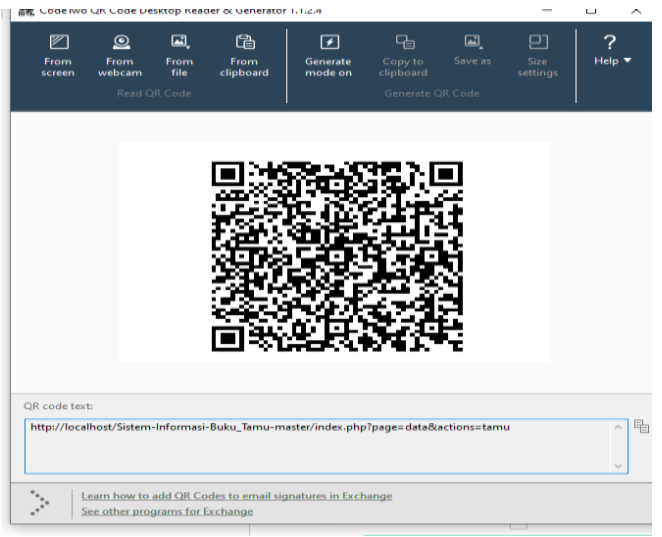

Gambar 10 hasil scan $Q R$ code

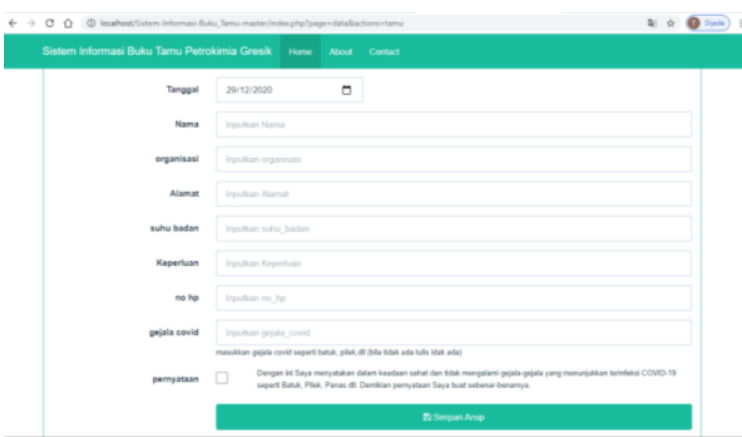

Gambar 11 page input data tamu

\section{Menu master data}

Pada menu ini admin dapat melihat semua tamu yang telah mengisi data menggunakan link yang telah di scan pada $Q R$ code. Fitur yang tersedia dalam menu ini meliputi verivikasi view, edit, delete, 
dan verifikasi data. Kemudian, menu tambah tamu dibagi menjadi 2 fitur, yakni tambah data dengan menggunakan $Q R$ code, maupun tambah data secara manual (non $Q R$ code).

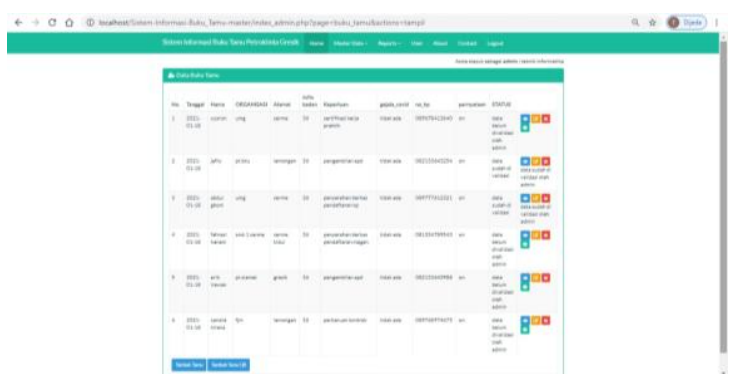

Gambar 12 menu master data

\section{Menu about}

Pada menu ini digunakan untuk sedikit menjelaskan tentang fungsi dari buku tamu berbasis web yang telah peneliti buat.

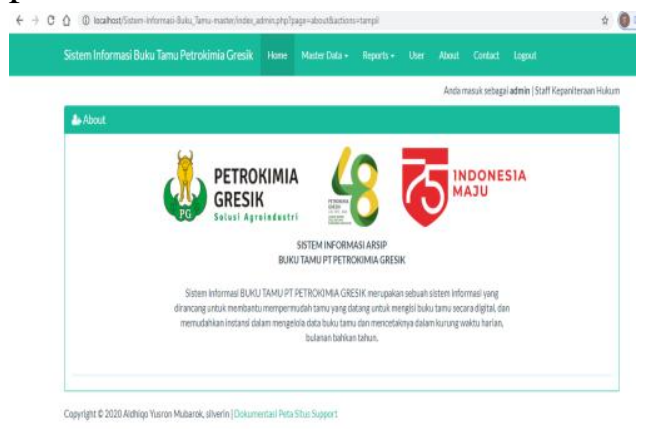

Gambar 13 menu about

\section{Menu reports}

Pada menu ini, disediakan fitur cetak data tamu yang telah berkunjung ke Petrokimia Gresik. Di sini peneliti masih menggunakan data dummy. Fitur ini memiliki beberapa pemilihan percetakan yakni : cetak semua buku tamu, cetak perbulan, dan cetak pertahun. Admin dapat memilih pilihan cetak yang dinginkan, apabila memilih cetak semua buku tamu maka semua data tamu dari awal aplikasi digunakan hingga sekarang akan di cetak, apabila admin memilih cetak perbulan, maka hasil yang di cetak akan disesuaikan dengan bulan yang ingin di cetak. Sedangkan yang terkahir adalah cetak pertahun, yakni mencetak data dalam tahun yang dipilih.

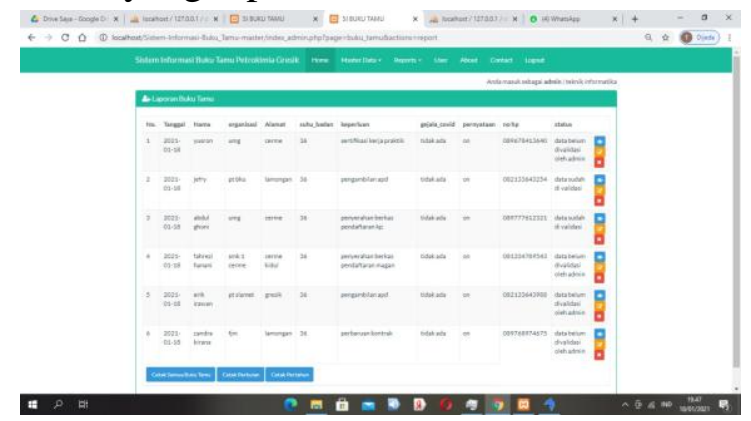

Gambar 14 menu reports

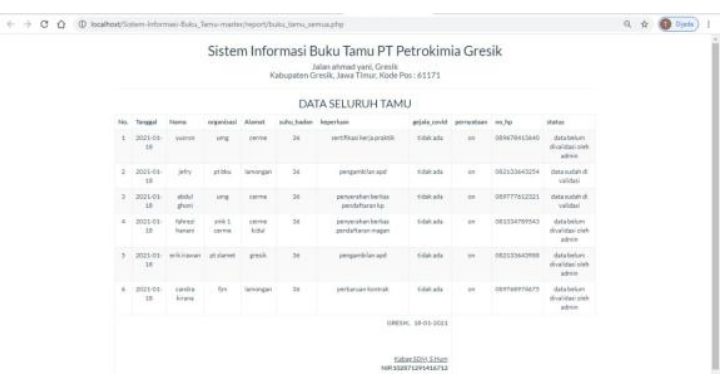

Gambar 15 hasil cetak data seluruh tamu

\section{Hasil uji sistem}

Fitur dalam sistem yang telah jadi akan didemokan oleh peneliti dan diuji oleh staf penganggung jawab IT Petrokimia Gresik. Dengan adanya pengujian pada sistem ini diharapkan sistem dapat digunakan pada PT Petrokimia Gresik. Hasil penilaian dapat dilihat pada gambar tavel dibawah ini : 


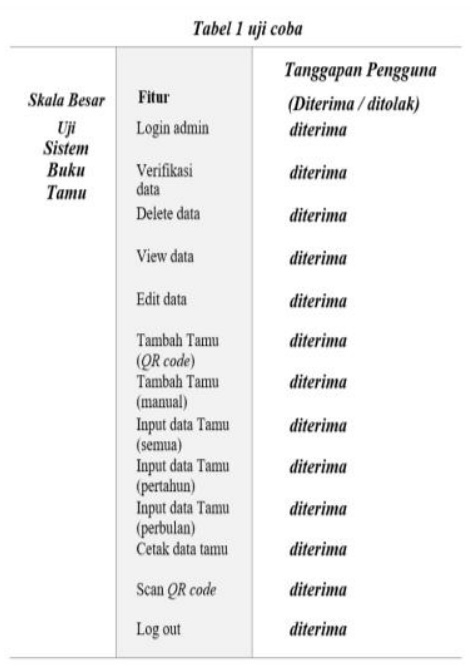

Gambar 16 tabel hasil pengujian

Dari hasil tabel tersebut setiap fitur yang disediakan sistem telah mendapat persetujuan oleh Petrokimia Gresik dan sistem dapat digunakan dengan baik.

\section{KESIMPULAN}

1. Penelitian ini telah mengasilkan sebuah produk berupa Sistem Informasi Buku Tamu Menggunakan QR code Berbasis Web Pada PT Petrokimia Gresik, untuk menangani kontak fisik secara langsung antar pegawai Petrokimia Gresik dengan tamu yang berkunjung. Dengan adanya sistem buku tamu karyawan maupun tamu tidak perlu untuk melakukan kontak fisik dengan satu sama lain.

2. Sistem informasi ini dibuat dengan menggunakan metode waterfall yang menggunakan bahasa pemerograman PHP, dengan MySql sebagai databasenya.

3. Sistem telah menjalani tes uji penerimaan dan dapat dinyatakan layak untuk digunakan.

\section{Saran}

Adapun saran untuk pengembangan penelitian ini kedepan yaitu mengembangkannya menjadi aplikasi android sehingga sistem dapat diakses lebih mudah baik oleh karyawan maupun tamu.

\section{DAFTAR PUSTAKA}

Mulyadi (2019) Aplikasi Buku Tamu Elektronik Pada Perpustakaan STIKOM Dinamika Bangsa Vol.4, No.1, Mei 2019, pp. 58 66, p-ISSN: 2527-449X, e-ISSN: 2549-7421

Rut Chrystin Saragi Napitu dkk (2020), Perancangan Sistem Absensi Berbasis Web pada Program Studi PTI UNIMUDA Sorong, Jurnal PETISI, Vol. 1, No. 2

Fery Wongso, (2016). Perancangansistem Pencatatan Pajak Reklame Pada Dinas Pendapatan Kota Pekanbaru Dengan Metode Visual Basic. Jurnal Ilmiah Ekonomi dan Bisnis Vol. 14, No. 2

O'Brien, A. James and George $\mathrm{M}$. Marakas, 2016. Analisa Sistem Informasi, Tata sutabri, Ed 1, Andy, Yogyakarta.

Supono, dan Putratama Vidiandry, (2016), Pemrograman Web dengan menggunakan PHP dan Framework Codeigniter, Yogyakarta: Deepublish.

Abdulloh, Rohi. (2016). Easy dan Simple Web Programming. Jakarta: Elex Media Komputindo.

Solichin, Achmad Pemrograman Web dengan PHP dan MySQL, Jakarta : Budi Luhur, 2016.

Madcoms (2016). Sukses Membangun Toko Online dengan PHP \& MySQL. Yogyakarta: Andi.

Rahaman, W. (2016). Enhancing Library Services Using Barcode, Qrcode and RFID Technology: A Case Study in Central Library National Institute of Technology Rourkela, International Journal of Digital Library Services, 6(3), 39-50. 
Wijaya, A. \& Gunawan, A. (2016).

Penggunaan $Q R$ Code Sarana

Penyampaian Promosi Dan

Informasi Kebun Binatang Berbasis

Android, Jurnal Bianglala, 4(1), 16-

21. 